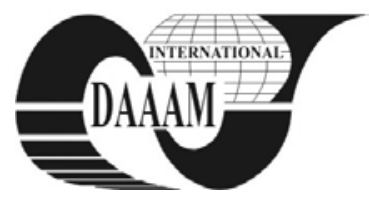

Annals of DAAAM for 2011 \& Proceedings of the 22nd International DAAAM Symposium, Volume 22, No. 1, ISSN 1726-9679 ISBN 978-3-901509-83-4, Editor B. Katalinic, Published by DAAAM International, Vienna, Austria, EU, 2011 Make Harmony between Technology and Nature, and Your Mind will Fly Free as a Bird Annals \& Proceedings of DAAAM International 2011

\title{
LABORATORY OF PRODUCTION SYSTEM CONTROL AND PROGRESSIVE EDUCATION METHODS
}

\author{
MUDRIKOVA, A[ndrea]; KOSTAL, P[eter]; DELGADO SOBRINO, D[aynier] R[olando] \& VLASEK, \\ M[atus]
}

\begin{abstract}
The paper describes the education process changes at production systems control laboratory and using the elearning to improve the educational process. The laboratory will be used for teaching automatic control principles and programming in flexible production via various control modes. We select the most often control modes used in the technical practice. In this laboratory there will be applied real elements of control systems. Teaching will be connected with progressive education methods including e-learning.
\end{abstract}

Key words: automation, production system, control, e-learning, programming

\section{INTRODUCTION}

The project KEGA 3/7131/09 - Program production system control laboratory building being solved by the Institute of Production Systems and Applied Mechanics at the Faculty of Materials Science and Technology of the Slovak University of Technology in Bratislava in years 2009 - 2011 represents an opportunity of students to obtain abilities and skills expected by employers. The project objective is to create a laboratory of control systems and a suitable teaching system supporting the students in acquisition of key and occupational competences and skills that would increase the level of their preparation for practice. The main advantage of this laboratory is that the students can work by the real industrial elements for production systems program controlling. The education will be realized by new progressive education methods including e-learning too.

\section{PRODUCTION SYSTEM CONTROL LABORATORY ADVANTAGES}

An important requirement of possible employers is the „proper“ ratio between professional competences (high level of professional knowledge and overview of actual trends in the branch) and key competences (Kundrátová, 2005).

A Professional competences ensure good management of work tasks,

A Key competences, as widely utilizable competences, e.g. ability to decide, solve problems, work in team, communicate in foreign language, learn, work with information, etc. (Belz \& Siegrist, 2001).

Of course, special, professional knowledges are inevitable and key competences help use them better in practice.

Identified competences that can be integrated into professional competences of an engineer are:

A Necessary habits and skills in experimental and laboratory works;

A Systematic approach to solving technical issues;

A Ability to apply special knowledge and skills in practice;

A Social responsibility (graduates should be aware of social, moral, legal, economic and environmental connections of their profession and consequences of their activities) (Kundrátová, 2005).
Work in the laboratory develops and improves computer literacy that is so important at present and last but not least definitely supports acquisition of other key and professional competences of graduates of our University of Technology.

\section{LABORATORY USING}

The teaching, development of cognitive operations (knowledge, skills and habits, i.e. improvement of key and professional competences) and also linkage with practice would be achieved by designing and modeling various manufacturing devices and their control systems in the laboratory by students. (Saniuk 2010) For that purpose special software will be installed which will actuate various elements of industrially used (Fig. 1), real production systems and their controls (PLC, step motors, various types of sensors, etc.). At the same time students will have an opportunity to prepare specifications and projects for various subjects taught in our curriculum to obtain their specialization and to prepare so for a real problem solving in practice what is really top-rated by employers.

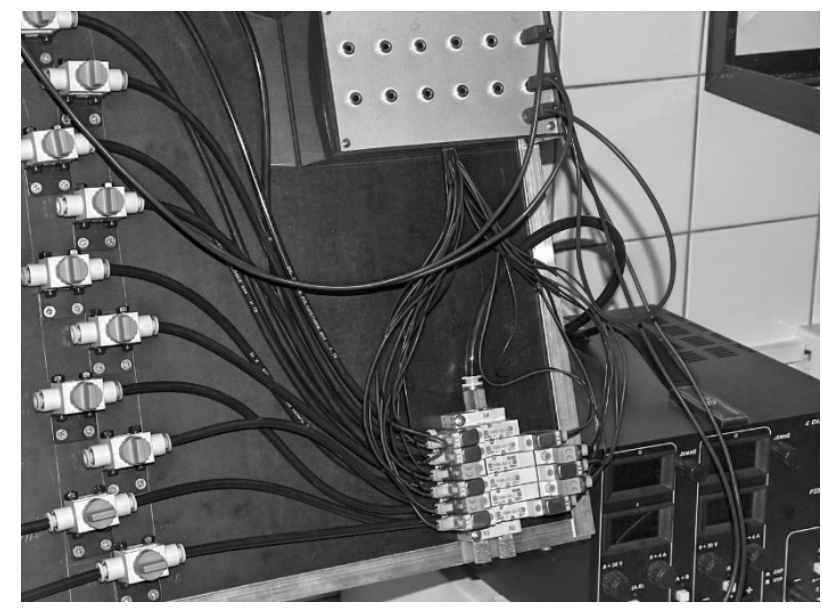

Fig. 1. Real industrial parts connection in the laboratory

\section{E-LEARNING}

E-learning as a progressive education form opens many new opportunities. This form can be used at all levels of formal education and also in life-long learning.

E-learning, as a new didactic method, facilitates distance learning and provides new possibilities for other education forms. Teachers become authors of educational, instructional documents with a specific mission - to transform the quality of all attendance forms of study into rationally configured documents in electronic form (Cagáňová, 2008).

Computers and other facilities gave rise to world wide communication network - internet. In present time internet represents the most extensive and most massive information and communication technology that enables both general and addressed bidirectional communication (Graczykm et al.,2010). 


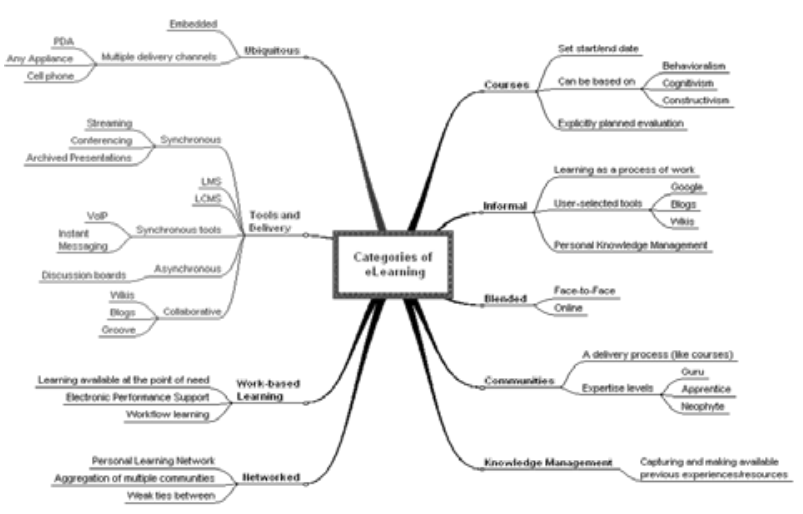

Fig. 2. Categories of e-learning

E-learning brings along a lot of communication tools starting with e-mails up to video-conferences enabling teachers to work with individual students. Based on feed-back the teacher is exactly informed about student's progress in individual lessons, the place and number of points achieved and time spent in individual education fields. Thanks to many communication channels the cooperation with the student can be more intensive compared with the classical education lessons.

The categories of elearning (Fig. 2.) (Siemens, 2004):

1. Courses - typically take existing educational materials, add various media, sequence the material and consider it "transferred" to the online environment.

2. Informal Learning - perhaps the most dynamic and versatile aspect of learning. Informal learning is a based on the human behaviour when searching for information.

3. Blended learning - involves classroom (or face-to-face) and online learning. This method is very effective for adding efficiency to classroom instruction and permitting increased discussion or information review outside of classrooms.

4. Communities - online communities allow people to stay current in their field through dialogue with other members of the same organization, or the larger global field.

5. Knowledge Management - involves the process of identifying, indexing, and making available (in various formats) knowledge generated within the daily activities of an organization.

6. Learning Networks - The utilization of personal learning networks allows knowledge workers to remain current in their field.

7. Work-based Learning (EPSS) - attempt to inject learning content into the actual point of need. As an alternative to courses, this style of content presentation requires heavy emphasis on context, and the employee control in initiating the learning needed. Work-based learning is generally and enterprise-wide initiative (Siemens, 2004).

All of presented methods has a its own advantages and disadvantages too. So is very important to choosing the proper method or its combination for a given case.

A convenient combination of „classical“ and electronic education (e-learning) creates new possibilities to implement ideas of the teacher and demands on students. This is a new look on university education method in which proficiency and experience of the teacher unite with advantages of information communication technologies.E-learning standards describe plenty of areas from hardware, via communication interface, up to didactics and meta-data. Standards are created by each organizer individually. (Lenhardtová et al., 2009)

For instance, students can be electronically „pre-trained“ also for areas where the personal contact with the teacher is considered to be inevitable. Such students come then to the teacher with a lot of information and questions and the teacher can deal only with the interesting or difficult parts of education and to shorten so the training time significantly.

\section{CONCLUSION}

E-learning and virtual/real labs represent modern ways of applying computer technology in various areas of our life and significantly and positively influence the qualification level of future leaders of our industry. However, education in this laboratory will increase competitiveness of our graduates at the present labour market in the Slovak Republic and within globalization also at the European labour market.

We plan to enhance our teaching through electronic online testing, remote monitoring and control of equipment in our laboratories at the Institute of Production Systems and Applied Mechanics.

We expect benefits as follows:

A Teaching process will be more attractive and effective for students thanks to its illustrativeness

A Students will adopt and strengthen their technical knowledge, skills and abilities

A Teaching process in this laboratory covers several subjects of several study programmes accredited in our Institute

A Competitiveness increase of our graduates at the labour market in Slovakia and Europe

A Utilization of tools, instruments and equipment that represent current industrial standard

A Students get familiar and will work with real industrial elements

\section{ACKNOWLEDGEMENTS}

This article was written thanks to support of the grant task KEGA 3/7131/09 - Program production system control laboratory building.

\section{REFERENCES}

Belz, H. \& Siegrist, M. (2001). Klićové kompetence a jejich rozvijeni: Východiska, metody, cvičeni a hry, Praha: Portál, ISBN 80-7178-479-6, Praha

Cagáňová, D. (2008). Syllabus design, In: Annals of DAAAM and Proceedings of DAAAM Symposium. Vol. 19, No.1. "Intelligent Manufacturing \& Automation: Focus on Next Generation of Intelligent Systems and Solutions", 22-25th October 2008, Trnava, Slovakia,. ISSN 1726-9679, ISBN 978-3-901509-68-1, pp. 0187-0188, DAAAM International Vienna, Vienna

Graczyk M.; Politowicz I. \& Witkowski K. (2010). Innowacyjność edukacji dla zrównoważonego rozwoju Myślenie kategoriami cyklu życia, In: Edukacja dla zrównoważonego rozwoju, T. 2, Edukacja dla ładu ekonomicznego, red. B. Poskrobko, Białystok - Wrocław, pp. 227-238, Wydaw: Ekonomia i Środowisko, ISBN: 97883-61643-68-5

Kundrátová, M. \& Mudriková, A. (2005). Survey of employers' requirements on key competences of graduates of technical universities, Proceeding of CO-MAT-TECH 2005, 13. Medzinárodná vedecká konerencia, 20.-21.10.2005, Trnava, Slovakia , Bratislava: STU, Trnava

Lenhardtová, Z.; Cagáňová, D. \& Gyurák Babel’ová, Z. (2009). Contemporary situation in the creativity area in the Slovak republic, In: Annals of DAAAM and Proceedings of DAAAM Symposium. Vol. 20, No. 1 "Intelligent manufacturing \& automation: Focus on theory, practice and education", 25 - 28th November 2009, Vienna, Austria, ISSN 1726-9679, ISBN 978-3-901509-70-4, pp. 0937-0938 Vienna : DAAAM International Vienna, Vienna

Saniuk S. (2010). Ocena pracownika jako element modelu zarządzania personelem małych i średnich przedsiębiorstw produkcyjnych. Problemy Profesjologii, nr. 2, pp. 95-104.

Siemens G. (2004). Categories of eLearning, Available from:http://www.elearnspace.org/Articles/elearningcategori es.htm Accessed: 2004-10-18 